Biroli, Flávia. 2016a. “Political Violence against Women in Brazil.” Direito ๒ Práxis 7 (15): $557-89$.

. 2016b. "Sobre Lutas, Avanços e Reações: Feminismos e a Reorganização das Esquerdas." In Encruzilhadas da democracia, eds. Luis Felipe Miguel and Flávia Biroli. Porto Alegre: Editora Zouk, 91-117.

- 2018. Gênero e desigualdades: limites da democracia no Brasil. São Paulo: Boitempo Editorial.

Cerva Cerna, Daniela. 2014. "Participación Política y Violencia de Género en México." Revista Mexicana de Ciencias Políticas y Sociales 59 (222): 105-24.

Collins, Patricia Hill. 2015. "Intersectionality's Definitional Dilemmas." Annual Review of Sociology 41: 1-20.

Inter-Parliamentary Union. 2018. "Women in National Parliaments: Situation as of 1 January 2018." http://archive.ipu.org/wmn-e/arc/world010118.htm (accessed March 7, 2018).

Krook, Mona Lena. 2017. "Violence against Women in Politics." Journal of Democracy 28 (1): 74-88.

Krook, Mona Lena, and Juliana Restrepo Sanín. 2016. "Gender and Political Violence in Latin America.” Política y Gobierno 23 (1): 125-57.

Machado, Lia Zanotta. 2016. "Brazilian Feminists in their Relations with the State: Contexts and Uncertainties." Cadernos Pagu 47: 1-37.

Matos, Marlise, and Clarisse Goulart Paradis. 2014. "Desafios à Despatriarcalização do Estado Brasileiro." Cadernos Pagu 43: 57-118.

Miguel, Luis Felipe, and Flávia Biroli. 2011. Caleidoscópio Convexo: Mulheres, Política e Mídia. São Paulo: Editora da Unesp.

Restrepo Sanín, Juliana. 2016. "Violence against Women in Politics and the Law." Presented at the 24th World Congress of the International Political Science Association, Poznan, Poland, July.

Young, Iris Marion. 1990. Justice and the Politics of Difference. Princeton, NJ: Princeton University Press.

\title{
Intersectional Violence against Women in Politics
}

\section{Rebecca Kuperberg, Rutgers University}

doi:10.1017/S1743923X18000612

The field of violence against women in politics (VAWIP) is so new, it seems unfair to discuss its "gaps"; rather, the study of VAWIP is defined by its uncharted territory. The bulk of existing literature, compiled by scholars as well as practitioners, emphasizes theoretical conceptualization, empirical forms of violence, and the tracking of incidents across regions (Krook 2017; Krook and Restrepo Sanín 2016). Researchers have stressed the gendered motivations and implications of VAWIP. In short, women 
are targets of violence because they are women and because they are in politics.

However, from intersectionality theory, we know that women do not have a single identity. Instead, they are impacted by intersecting structures of oppression that include, but are not limited to, sexism. Identities are multifaceted and intertwined; accordingly, structures of oppression and privilege interact. I apply an intersectional lens to VAWIP through three questions: How is VAWIP intersectional? What methods can we utilize to conduct an intersectional analysis? Finally, what can an intersectional approach add to our understanding of VAWIP theoretically and empirically?

\section{VAWIP AND INTERSECTIONALITY}

I define VAWIP as acts or threats of violence resulting in physical, psychological, or symbolic harm or suffering to women involved in, or associated with, politics (Kuperberg 2017). Violence against women in politics differs from other forms of violence in that it (1) emphasizes the political arena; (2) centers targets and survivors of violence, in this case women in politics, rather than politicians accused of violence; and (3) has implications for global democracy and gender equality.

Intersectionality theory, born out of black feminism in the United States, argues that multiple forms of discrimination are not "purely additive" but instead function as simultaneous oppressions with a multiplicative effect (King 1988, 46). The term is attributed to Kimberlé Crenshaw (1989), but the intersections she conceptualizes were articulated previously by Deborah King, the Combahee River Collective, Sojourner Truth, and others, including activists outside the United States (Tormos 2017, 708). Many have voiced concerns over intersectionality traveling beyond its roots in black American feminism (Yuval-Davis 2006). However, once we understand intersectionality as historically articulated in global activism and a concept now enshrined in international law, the question is no longer whether intersectionality should travel, but instead, where it can go.

\section{HOW IS VAWIP INTERSECTIONAL?}

Intersectionality is lauded as the most important theoretical contribution, to date, offered by women's studies (McCall 2005, 1771). We understand 
individuals as having intersecting identities, and living in a world with intersecting axes of discrimination. Women in politics are not a homogenous group, and their experiences in politics are not limited to their gender alone. However, intersecting axes of oppression remain peripheral to existing understandings of VAWIP.

To more thoroughly understand VAWIP, and to craft appropriate policies to mitigate this violence, we need to take into account intersecting structures of oppression. Amnesty International's (2017) study of online violence against British members of Parliament (MPs) illustrates the insights gained by taking an intersectional approach. Analyzing the Twitter accounts of all 177 female MPs in the six months prior to the 2017 elections, the study revealed not only the sheer volume of abusive tweets leveled at female MPs - 25,688 over the six-month period - but also racial dimensions of the abuse. Diane Abbott, Britain's first black female MP, received just over $45 \%$ of tweets coded as "abusive." When Abbott is excluded from the analysis, black and Asian MPs still received 35\% more abusive tweets than white women MPs.

Intersectional approaches, however, do not need to be restricted to interactions between race and gender. In a pilot study conducted in Israel, using interview data and social media analysis, I found that quantities of violent tweets to female members of parliament differed primarily by party identification. Over a small time period in January 2017, approximately $2.5 \%$ of tweets mentioning the Twitter handles of female MPs were abusive. However, parties on the left (5.3\%) and right (3.4\%) saw much more violence than centrist parties (less than $1 \%$ ). In the broader global context, this finding makes sense, as sitting politicians are often targeted by both far-left and far-right abuse. If we understand VAWIP, at least in part, as backlash to women's political progress, noncentrist women may be perceived as greater transgressors and more threatening to the political status quo.

Many of these abusive tweets combined both partisan and gendered slurs. For example, a user commented on a post made by Green MP ${ }^{1}$ Yael Cohen Paran with the following: "We're pissing on you. And what you represent." Stav Shaffir, also a member of the primary leftist party and the youngest parliamentarian sworn in to the 19th Knesset, was described as a "leftist prostitute."

Abuse based on MP ethnicity, religion, and age - which MPs identified as key components of VAWIP in my interviews - were small or

1. Co-chair of the Greens but included on the Labour list, enabling her ascension to the Knesset. 
nonexistent. Importantly, however, the discourse of the abusive tweets included sexist, Islamophobic, and racist language. Therefore, we need to consider not only how the identities of female parliamentarians might motivate VAWIP but also how forms of VAWIP reflect different structures of oppression. By looking at both the motivations and forms of VAWIP, we will have a more nuanced understanding of the implications of VAWIP.

As these two studies indicate, women do not only experience violence and harassment on their basis of their gender. For women in politics, VAWIP can also be informed by ability, sexuality, race and ethnicity, religion, national origin, language, religiosity, age, or geography. Depending on context, these structures will vary in their salience. For example, some countries may be religiously homogenous, and therefore religious difference is unlikely to be a salient variable that determines opposition to women in politics. However, even in a religiously homogenous country, denominational differences or degrees of religiosity may be important categories of difference, yielding unique forms of oppression. As studies of intersectional VAWIP expand to additional cases, we will have a better idea of how structures interact differently in distinct contexts.

\section{WHAT METHODS CAN WE UTILIZE TO CONDUCT AN INTERSECTIONAL ANALYSIS?}

There are clear methodological challenges in studying VAWIP. Susan Brownmiller, in reference to statistics on sexual assault, wrote, "Statistical analysis is a valuable tool when it deals with a reported crime. Unreported crime, however, remains beyond the magic of computers" (1975, 173). For survivors, reporting VAWIP may be problematic because of concerns over retaliation, taboos, and social and political pressures not to publicize political acts of violence. An intersectional study is beset with additional challenges. For example, how do we determine which structures of oppression are most salient in a given context? I argue that we should work with local partners and let women in politics identify the structures that influence the violence they experience. At the very least, these considerations should serve as a base from which research can expand and develop.

While intersectionality research is not limited to a single method, scholars have recognized the benefits of qualitative research. Mary Hawkesworth writes that techniques "devised to reveal uniformities of behavior are by design insensitive to difference, treating anything that 
deviates from the norm as an outlier or anomaly" (2003, 532). Social media data, which is not only accessible but plentiful, provide a great starting point. However, analyses that count tweets without incorporating discourse will not be able to account for nuance, new abusive rhetoric, or subtle differences in language. Further, in the Israeli case, interview and social media data diverged markedly. Utilizing multiple methods such as both big data and qualitative discourse analysis - will enable a greater understanding of violence in the halls of politics, in cyberspace, and in locations in between.

\section{HOW DOES OUR CONCEPTUALIZATION OF VAWIP CHANGE WHEN OUR METHODS ARE INTERSECTIONALLY INSPIRED?}

When we utilize an intersectional approach, I argue, we will find that women in politics experience violence that is not only gendered but also lies at the intersection of many axes of discrimination. We need to consider not only the motivations of perpetrators and the identities of the politicians themselves but also the issues they support and vocalize. Additionally, we need to place VAWIP in its geographic context, recognizing the similarities across cases as well as key differences.

An intersectional approach to VAWIP encourages research that identifies violent discourse experienced by a host of politically marginalized groups. VAWIP importantly centers women in politics rather than perpetrators of violence. But men of marginalized groups or those who support marginalized groups can experience similar forms of violence and harassment. For example, gendered language has been used as a tool to diminish men in politics who do not conform to standards of hegemonic masculinity (Fahey 2007). Though not currently understood within the frame of VAWIP, these acts of gender-based violence can be better understood through VAWIP's theoretical contributions. As with many areas of political science, in conceptualizing from the periphery, we can gain a greater understanding of politics as a whole.

Rebecca Kuperberg is a Ph.D. Candidate in Political Science at Rutgers University, New Brunswick, New Jersey: rebecca.kuperberg@rutgers.edu

\section{REFERENCES}

Amnesty International. 2017. Black and Asian Women MPs Abused More Online. https:// www.amnesty.org.uk/online-violence-women-mps (accessed March 7, 2018). 
Brownmiller, Susan. 1975. Against Our Will: Men, Women and Rape. New York: Simon \& Schuster.

Crenshaw, Kimberlé. 1989. "Demarginalizing the Intersection of Race and Sex." University of Chicago Legal Forum 1989(1): 139-67.

Fahey, Anna Cornelia. 2007. "French and Feminine: Hegemonic Masculinity and the Emasculation of John Kerry in the 2004 Presidential Race." Critical Studies in Media Communication 24 (2): 132-50.

Hawkesworth, Mary. 2003. "Congressional Enactments of Race-Gender." American Political Science Review 97 (4): 529-50.

King, Deborah K. 1988. "Multiple Jeopardy, Multiple Consciousness.” Signs 14 (1): $42-72$

Krook, Mona Lena. 2017. "Violence against Women in Politics." Journal of Democracy 28 (1): 74-88.

Krook, Mona Lena, and Juliana Restrepo Sanín. 2016. "Violence against Women in Politics: A Defense of the Concept." Politica y Gobierno 23 (2): 459-90.

Kuperberg, Rebecca. 2017. "Sexual Violence against Women in Politics." Unpublished manuscript.

McCall, Leslie. 2005. "The Complexity of Intersectionality." Signs 30 (3): 1771-1800.

Tormos, F. 2017. "Intersectional Solidarity." Politics, Groups and Identities 5 (4): 707-20. Yuval-Davis, Nira. 2006. "Intersectionality and Feminist Politics." European Journal of Women's Studies 13 (3): 193-209.

\section{Making Gender Visible in Election Violence: Strategies for Data Collection}

\section{Elin Bjarnegård, Uppsala University}

doi:10.1017/S1743923X18000624

Election violence is an important issue from a number of perspectives. Understanding the causes and consequences of violations of personal integrity is always relevant, but election violence adds a different dimension to this already serious issue: it also violates electoral integrity and decreases democratic quality (Norris 2013). Therefore, election violence should be studied as a simultaneous violation of personal and electoral integrity. In this contribution, I define election violence as occurring when (1) the goal of the act is to affect an electoral outcome or prevent someone from running in an election, and (2) the means by which it is carried out violates the personal integrity of individuals involved in the electoral process.

From existing research on gender and violence, we know that men and women are prone to fall victim to different types of violations of personal 